\title{
Analysis of Upper Arm Circumference Using Statistical Approach as a Risk Factor of Stunting Cases
}

\author{
I Gede Wiryawan* \\ Information Technology Department \\ Politeknik Negeri Jember \\ Jember, Indonesia \\ wiryawan@polije.ac.id
}

\author{
Huda Oktava \\ Clinical Nutrition Department \\ Politeknik Negeri Jember \\ Jember, Indonesia \\ huda_tp@yahoo.com
}

\author{
Ely Mulyadi \\ Information Technology Department \\ Politeknik Negeri Jember \\ Jember, Indonesia \\ elymulyadi@polije.ac.id
}

\author{
Prawidya Destarianto \\ Information Technology Department \\ Politeknik Negeri Jember \\ Jember, Indonesia \\ prawidya@polije.ac.id
}

\author{
Khafidurrohman Agustianto \\ Information Technology Department \\ Politeknik Negeri Jember \\ Jember, Indonesia \\ khafid@polije.ac.id
}

\begin{abstract}
Stunting as a condition of failure to thrive in children under five is an event that has received special attention from the government. The state of stunted babies has measured the height or length of the baby's body that is less than minus two standard deviations of the child's median standard of growth. The purpose of this study was to determine the effect of infant upper arm circumference on the incidence of stunting. This study was an observational analytic study using a statistical method approach in the analysis of these effects, specifically case-control design method. The results showed that the upper arm level could affect the incidence of stunting in toddlers. The value of odd ratio evidenced this; it was 9.577. In the future, medical personnel can consider the results of this study in predicting the possibility of early cases of stunting so they can do prevention early.
\end{abstract}

Keywords - upper arm circumference, stunting, statistic

\section{INTRODUCTION}

Stunting, which is commonly called the occurrence of stunted or stunted babies, is a condition in which the development of infants under five years of age (toddlers) has less length or height compared to period. In other words, it can also be mentioned as a condition of failure to thrive in children under five[1]. The stunting case that occurs in Indonesia has received special attention from the government. It can be seen from the Indonesian Basic Health Research Report (Riskesdas), where there was a decrease in the number of infants under five who experienced stunting by $6.4 \%$ from 2013 to $30.8 \%$ in 2018 [2].

The decline in the percentage of children under five who stunted in Indonesia has not yet met the minimum standards set by the World Health Organization (WHO). The WHO standard rate is $21.9 \%$ [3]. This figure is the global average percentage of children under five who stunted, and has become a target for child malnutrition from the Sustainable Development Goals (SDGs).
Based on the 2018 Riskesdas for East Java Province, Jember Regency has a proportion value of very short and stunting nutritional status, which is still higher than the average amount of other districts in East Java Province. Therefore, with research that discusses stunting, it is hoped that a way to prevent stunting can be found. Several studies on stunting have been conducted in Jember Regency before. The first study analyzed the factors that influence stunting in children under five in the working area of a public health centre[4][5]. Subsequent research re-analyzed the factors that influence the incidence of stunting in children under five in urban and rural areas[1][6].

Many factors influence the incidence of stunting in Indonesia. First is the health and nutritional condition of the mother before and during pregnancy and after delivery. Other factors that also influence include the mother's posture (short), the pregnancy is too close; mothers who are still teenagers, and insufficient nutritional intake during pregnancy. Besides, there are also factors from the baby's condition, namely the necessity of illness and lack of nutritional intake in the baby[7]. In addition to elements from mother and baby, there are also factors from socio-economic and environmental conditions.

Measuring the condition of infants who stunted is by measuring the height or length of babies that are less than minus two standard deviations from the WHO's median standard of child growth. This study will analyse the relevance relationship between the upper arm circumference (LiLA), both pregnant women and babies, to other factors that influence stunting conditions of infants[8]. Stunting is not only caused by one factor but also caused by many factors where these factors are interrelated with one another. We can use LiLA as a consideration in assessing the nutritional status of pregnant women and women of fertile age (WUS).

We can determine the nutritional status of pregnant women by measuring the size of the upper arm circumference (LILA) if it is less than $23.5 \mathrm{~cm}$, the pregnant woman is 
considered less energetic (KEK). So that the pregnant woman can be at risk of giving birth to a low birth weight baby (LBW). Compared to other anthropometric indicators, LILA practical use in the field can be prepared easily with inexpensive funds and does not require intensive training in the skills to use it [8].

The purpose of this study determines the circumference of the upper arm's relationship to the incidence of stunting that has occurred. The results of this study were to increase the variety of variables as a consideration in preventing stunting. The method used is a statistical method approach such as an observational analytic study with a case-control design method, where the researcher had used the technique widely previously in similar research. The novelty of this study was using the variable upper arm circumference (LiLA) as a variable that has an influence on the incidence of stunting.

\section{RELATED WORKS}

Before this study was carried out, many studies discussed the factors that influence stunting cases in certain areas. The first study related to this study was the study that aimed to analyze the factors that influence of stunted growth cases to children under five years old in the work area of Arjasa Public Health Center in Jember Regency[4][5]. This study was the observational analytic study with a quantitative approach. Based on the period of conduct, this study was cross-sectional study. The results of statistical analysis used double logistic regression show that the factors which influence the problem of this study were a history of infectious disease and pattern consumption of the liver as a risk factor. While the pattern of pre lacteal, pattern of exclusive breastfeeding, the way of breastfeeding companion (pasi), genetic characteristics of mothers, and the pattern of consumption of iodine capsules as a protective factor. This study was collecting 40 cases and 80 controls as a sample.

In reference [5], the characteristics of children under five aged between 25 and 36 months, male sex, complete immunization status and born without LBW ( $\geq 2500$ grams). While the characteristics of mothers under five are mostly low education level, the age of the mother at pregnancy is between 20 and 34 years; the mother is not working, has a family income of above IDR 830,000. The level of knowledge of the mother's nutrition is lacking. 2 variables influence and become a risk factor, namely a history of infectious disease and liver consumption patterns. Meanwhile, four variables that have a significant effect and become a protective factor are the pattern of pre-lacteal administration, the way of exclusive breastfeeding, the pattern of giving pasi, maternal genetic factors and iodine capsule consumption patterns. It occurs because the infection can reduce food intake, interfere with the absorption of nutrients, causing direct loss of nutrients.

The next study looking at cases of stunting was identifying risk factors for stunting among children between the ages of 6 and 59 months[9]. It obtained the data by interviewing those children's mothers and measured length/height of 118 children as cases and 236 children as controls[9]. Logistic regression analysis was performed to identify the best model of factors leading to stunting, odds ratio and $95 \%$ confidence interval were used as a measure of association[9]. As a result, socio-economic risk factors for stunting comprised mothers without earning, food-deficit families and caretaker of the children other than mother[9]. Environmental risk factors for stunting consisted of the kitchen without ventilation and children exposed to a pesticide[9]. Inappropriate exclusive breastfeeding, complementary feeding less than four times a day and dietary diversity below WHO standard were factors of stunted children[9]. Diarrhea was found significantly associated with stunting. The study concluded that stunting found to be as a result of multiple factors such as socioeconomic, environmental and inappropriate feeding practices. All these factors should be taken into consideration to address stunting in the community[9].

Furthermore, there was a study analyzing the factors that influence the genesis of stunting in toddlers between rural and urban areas[6]. It used an observational analytic with crosssectional approached and conducted in Patrang health centre and Mangli health centre for urban whereas Kalisat health centres for rural, where the number of the sample were fifty respondents in each health centre. The sampling technique used in this study was random cluster sampling[4]. It analyzed the data by using chi-square test, Mann Whitney test and logistic regression with $\alpha=0,05$. The result showed that affecting factors of stunting occurrence in toddlers who are in the rural and urban areas were the mother's education, family income, mother's knowledge of nutrition, exclusive breastfeeding, complementary feeding age provision, zinc and iron adequacy level, infection disease history and genetic factors. Other factors such as mother's work, family numbers, immunization status, energy adequacy level and low birth weight (bblr) status didn't affect the cases of stunting. In rural areas, protein and calcium adequacy level showed a significant relation. Meanwhile, it showed no concern in urban areas.

Many studies have linked several variables to the incidence of stunting in certain areas, such as maternal characteristics, maternal parenting, nutritional care, anaemia status of pregnant women, and birth length[10]-[13]. It uses various kinds of analysis techniques, such as the Pearson Product Moment and Rank Spearman statistical tests. Besides, there was also an observational analytic study with a casecontrol design method and a logistic regression test. In continuing these previous studies, now these study linked a variable, the circumference of the upper arm, to the incidence of stunting.

Many studies discuss the circumference of the upper arm. The majority of these studies attempted to link upper arm circumference to the condition of the baby's birth[8], [14], [15]. One of the studies that used upper arm circumference with infant birth conditions was a study that analyzed the association of upper arm circumference with the risk of preterm birth. By using 105 samples of data in the form of medical records of patients who underwent labour at a health centre, this study found that there was no relationship between upper arm circumference less than $23 \mathrm{~cm}$ and the risk of preterm labour $(\mathrm{p}=0.256)$.

The next study was an epidemiological study analytic observational with a case-control study design [14]. The relationship between upper arm circumference less than $23 \mathrm{~cm}$ (risk factors) and the incidence of preterm labour (cases) was analyzed using the Chi-Square bivariate test (comparative analysis). There was a significant difference (the null hypothesis was rejected) if P less than 0.05. Meanwhile, how often the exposure in cases is presented in the odds ratio (OR). 
Then there is a reference [13] which discusses the circumference of the upper arm as well, Still, the difference is that the circumference of the upper arm is associated with the birth weight of the baby. This study is a descriptive-analytic study with a cross-sectional design. The population was all mothers who recorded as having performed pregnancy checks and giving birth in a maternity hospital, namely 112 cases, and the entire population used as a sample (total sampling).

The data analysis used in this study was univariate and bivariate, where the bivariate analysis used the chi-square test. The results showed that the upper arm circumference was more than equal to $23.5 \mathrm{~cm}(99.1 \%)$, then the upper arm circumference was less than $23.5 \mathrm{~cm}(0.9 \%)$. Birth weight of infants more than equal to 2500 grams $(95.5 \%)$, birth weight of infants less than 2500 grams $(4.5 \%)$ and there is a significant relationship between upper arm circumference of pregnant women and birth weight of babies.

Studies analyzing the relationship of the same variables as previous studies have also been conducted[8]. However, the location for collecting data from this study is different. This study was analytic with a cross-sectional design, and the sampling was carried out by using consecutive selection. The number of the sample was 85 respondents, including pregnant women who gave birth. The data of this study derived from the primary data, such as identities data of pregnant women, MUAC measurements and infant's birth weight.

The difference between this study and the related studies previously described is in the using of the variables. This study uses the upper arm circumference variable as one of the variables that affect the incidence of stunting[4]. So, the novelty of this study lies in these variables so that in the future it can be taken into consideration in preventing or perhaps handling cases of stunting suffered by children under five.

\section{METHODS}

The stages in this study started from the literature study and variable identification. In this first stage, several papers or articles from studies related to this study are obtained. Most of the related studies have linked several variables to the incidence of malnutrition or stunting from different locations. The variables used in the related study included anemia status, mother's parenting style, exclusive breastfeeding, etc [4][10][11][13][16]. The methods and approaches used in these related studies also vary, such as the Multivariate Adaptive Regression Splines (MARS) method, cross sectional analytic, case control analytic, etc [1] [12] [13][17].

TABLE I. DISTRIBUTION OF UPPER ARM CIRCUMFERENCE DATA

\begin{tabular}{|l|c|c|}
\hline Status Upper Arm Circumference & F & \% \\
\hline Standard (above $23.5 \mathrm{~cm}$ ) & 66 & 90.4 \\
\hline Abnormal (below $23.5 \mathrm{~cm}$ ) & 7 & 9.6 \\
\hline Total & 73 & 100 \\
\hline
\end{tabular}

The next stage is data collection. The data taken in this study are variable related to pregnant women and the incidence of stunting. The variables used in this study include upper arm circumference as the independent variable and the stunting cases as the dependent variable. The population of data obtained in this study are data from the clinic of dr. M.
Suherman, Jember. The time interval for this data collection is between June and August 2020, as for the number of data obtained is 73 data. Data collection techniques used are primary data collection. Table I shows the distribution of upper arm circumference data.

The upper arm circumference data obtained were then categorized into two categories, namely standard and abnormal. Where for the average upper arm circumference is above $23.5 \mathrm{~cm}$. The data were analyzed using a case-control design method, so this study is classified as an observational analytic study. The use of this method in this study is because there have been previous studies. The technique appears to be a good fit for several similar case studies.

After obtaining the data, the next step is processing the data. In this study, a bivariable analysis was carried out to test the relationship between two related variables. The research was carried out to determine the relationship between upper arm circumference and stunting using the chi-square \& OR (odds ratio) statistical test. Chi-square is a correlation test used to determine the relationship between 2 variables with a nominal data scale. This correlation test is to determine the relationship between stunting cases and the circumference of the upper arm. Computerized calculations with interpretation using a p-value of 0.05 with a precision of 5\%, then it is said to be related if the p-value is less than equal to $0.05 \%$ if it is considered unrelated.

In addition, a $2 \times 2$ matrix was used to obtain the odds ratio from the analysis of the relationship between upper arm circumference and the incidence of stunting[4]. Equation (1) is the formula used to calculate the odds ratio value.

$$
O R=\frac{\mathrm{a} \times \mathrm{c}}{\mathrm{b} \times \mathrm{d}}
$$

Where $a$ is the number of issues that have occurred, $b$ is the control of patients that have occurred, $c$ is the number of cases that have not occurred, and $\mathrm{d}$ is the control for cases that have not occurred. If the calculation of the odds ratio is more than one and the interval range does not include 1, it means that the variable upper arm circumference is a risk factor for stunting.

The final stage of this study, before conclusions can be drawn, is to analyze the results of the previous data processing stage. Figure 1 below shows the stages carried out during this study.

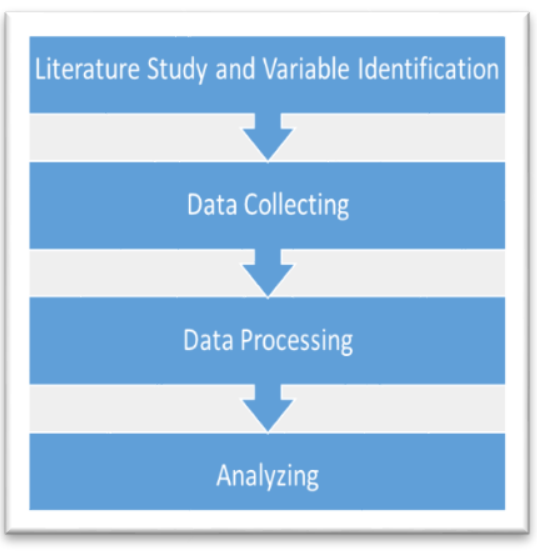

Fig. 1. The stages of study 


\section{RESULT \& DISCUSSION}

The incidence of stunting reflects a process of failure to achieve potential linear growth as a result of health and nutritional status[18]. Linear growth or height is influenced by genetic factors, environment, and medical conditions. The development of stunting is a chronic, gradual process, including malnutrition and infectious diseases, throughout linear growth. It often begins in the uterus and extends through the first two years.

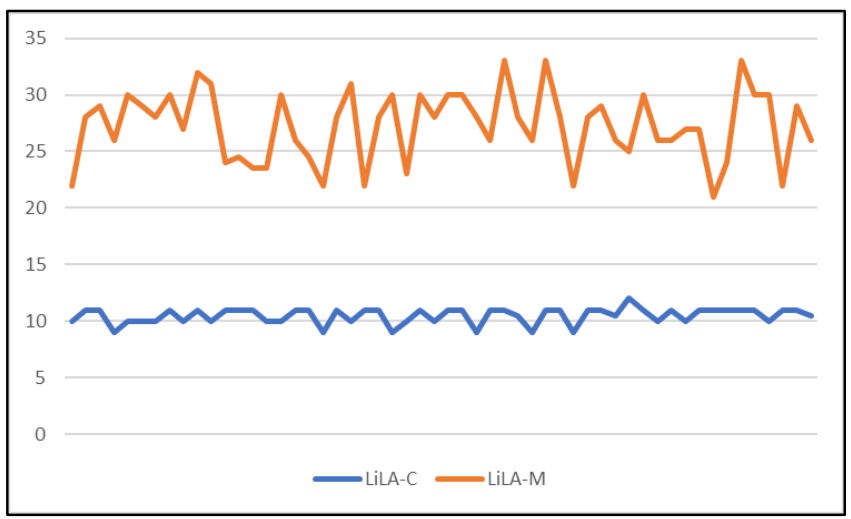

Fig. 2. The graphs of data collection

Figure 2 above shows the results of the variation in data obtained during the data collection stage. The orange line on the graph shows the circumference of the mother's upper arm (LiLA-M), while the blue line is the circumference of the child's upper arm (LiLA-C). The graph shows that if the orange line is at the lowest point, then some of the lows are also on the blue line.

Table II shows that there is a relationship between stunting cases and upper arm circumference during pregnancy. It is seen from the p-value is 0.00001 and OR $9,577(95 \% \mathrm{CI}$; $0.821-0.945)$ which means pregnant women with abnormal upper arm circumference 9.5 times greater risk of having a stunted child. The results of this study are in line with the results of previous related studies. Reference [11] revealed that external maternal circumstances, such as her maternal education and work, did not associate with the stunting cases. Likewise, the results obtained that the circumference of the upper arm has a significant effect on stunting cases in this study.

TABLE II. RELATIONSHIP BETWEEN UPPER ARM CIRCUMFERENCE AND STUNTING CASES

\begin{tabular}{|l|c|c|c|c|c|c|}
\hline \multirow{2}{*}{\begin{tabular}{c}
\multirow{2}{*}{$\begin{array}{c}\text { Stunting } \\
\text { Cases }\end{array}$} \\
\cline { 2 - 5 }
\end{tabular}} & \multicolumn{4}{|c|}{$\begin{array}{c}\text { Upper Arm } \\
\text { Circumference }\end{array}$} & \multirow{2}{*}{\begin{tabular}{c}
\multirow{2}{*}{ RO 95\% } \\
Ro
\end{tabular}} \\
\cline { 2 - 5 } & $\mathrm{F}$ & $\%$ & $\mathrm{~F}$ & $\%$ & & $\begin{array}{c}\text { Abnormal } \\
\text { Upper) }\end{array}$ \\
\hline Stunting & 2 & 65.5 & 5 & 37.1 & \multirow{2}{*}{0.00001} & $\begin{array}{c}9.577 \\
(0.821-0.945)\end{array}$ \\
\hline $\begin{array}{l}\text { No } \\
\text { Stunting }\end{array}$ & 71 & 34.5 & 68 & 62.9 & & \\
\hline Total & 73 & 100 & 73 & 100 & & \\
\hline
\end{tabular}

Upper arm circumference is an indicator of nutritional status in pregnant women. The circumference of the upper arm describes the amount of protein stored in the body. The World Health Organization classifies the upper arm circumference into three groups to determine the nutritional status of pregnant women. Upper arm circumference less than $23 \mathrm{~cm}$ indicates undernutrition status, upper arm circumference between 23 and 33 indicates normal nutritional status, while the upper arm circumference greater than $33 \mathrm{~cm}$ indicates obesity.

From the results of the bivariable analysis, it is known that the relationship between the independent variables is stunting status and the dependent variable. If the study results are associated with the study objectives, this study found a significant relationship between the variable upper arm circumference (LiLA) and the incidence of stunting.

The results of this study also reflect the results of previous studies that analyzed the variable upper arm circumference for birth conditions[8][15]. Both studies conclude the same analysis results, namely that there was a significant relationship between the upper arm circumference of pregnant women and the birth weight of the baby. The results of this study explain that the better the upper arm circumference of pregnant women[19], the more potential the mother will give birth to babies who did not experience stunting cases.

The results of this study, of course, can continue to be improved in terms of the methods used. The analytic case control design method is a method with a simple statistical approach. Methods in the application of data mining can be used as further research in increasing the use of the upper arm circumference variable as a factor in determining its effect on the incidence of stunting or malnutrition.

\section{CONCLUSION}

As a conclusion of this study, upper arm circumference associated with the incidence of stunting in children under five. The majority of mothers with stunting characteristics of children under five are below average forearm circumference. It can happen because, during pregnancy, the mother is not getting enough nutritional intake. A significant relationship between stunting cases and upper arm circumference during pregnancy showed from the p-value is 0.00001 and OR 9,577 (95\% CI; $0.821-0.945)$ which means pregnant women with abnormal upper arm circumference 9.5 times greater risk of having a stunted child. As a suggestion for future research, computational methods that are more data mining can be used for the same case in this study. This is because the method with the data mining approach can be used as a method to predict the incidence of stunting early on.

\section{ACKNOWLEDGMENT}

We thank the Ministry of Education and Culture and Politeknik Negeri Jember for the funding support through the scheme of PNBP 2020. We also thank Klinik dr. M. Suherman to allow the researchers get the data used in this research.

\section{REFERENCES}

[1] D. M. Azizah and E. O. Permatasari, "Modeling of toddler stunting in the province of east nusa tenggara using multivariate adaptive regression splines (mars) method," J. Phys. Conf. Ser., vol. 1490, no. 1, pp. 0-9, 2020.

[2] Kemenkes RI, "Laporan Hasil Riset Kesehatan Dasar (Riskesdas) Indonesia tahun 2018," Jakarta, 2018.

[3] WHO, "World health statistics 2019: monitoring health for the SDGs, sustainable development goals," Geneva, 2019.

[4] Miranti et al., "Determinants of the incidence of stunting in the working area of Kinovaro Sigi Health Center," Enfermería Clínica, vol. 30 , pp. 246-252, 2020. 
[5] Fajaria Kartikawati; Puji Rahayu, "Faktor yang Mempengaruhi Kejadian Stunted Growth pada Anak Balita di Wilayah Kerja Puskesmas Arjasa Kabupaten Jember,” Universitas Jember, 2011.

[6] F. O. Aridiyah, N. Rohmawati, and M. Ririanty, "Faktor-faktor yang Mempengaruhi Kejadian Stunting pada Anak Balita di Wilayah Pedesaan dan Perkotaan (The Factors Affecting Stunting on Toddlers in Rural and Urban Areas)," Pustaka Kesehatan; Vol 3 No 1, vol. 3 , no. 1, pp. 163-170, Jan. 2015.

[7] Pusdatin, "Situasi Balita Pendek (STUNTING) di Indonesia," in Buletin Jendela Data dan informasi Kesehatan, vol. 1, no. 1, Jakarta: Pusat Data dan Informasi Kemenkes RI, 2018.

[8] A. R. Putri and A. M. Al Muqsith, "HUBUNGAN LINGKAR LENGAN ATAS IBU HAMIL DENGAN BERAT BADAN LAHIR BAYI DI RUMAH SAKIT UMUM CUT MEUTIA KABUPATEN ACEH UTARA DAN RUMAH SAKIT Tk IV IM.07.01 LHOKSEUMAWE TAHUN 2015," AVERROUS J. Kedokt. dan Kesehat. Malikussaleh, vol. 2, no. 1, p. 1, 2018

[9] R. Paudel, B. Pradhan, R. R. Wagle, D. P. Pahari, and S. R. Onta, "Risk factors for stunting among children: A community based case control study in Nepal," Kathmandu Univ. Med. J., vol. 10, no. 39, pp. 18-24, 2012.

[10] D. K. Astuti, D. Sarbini, and L. R. Rakhma, "Hubungan Karakteristik Ibu Dan Pola Asuh Gizi Dengan Kejadian Balita Stunted di Desa Hargorejo Kulon Progo DIY." Universitas Muhammadiyah Surakarta, 2016.

[11] F. S. W. Vitaloka, "Hubungan Status Anemia Ibu Hamil dengan Kejadian Stunting Balita Usia 24-59 Bulan di Wilayah Kerja Puskesmas Gedangsari II Gunung Kidul," Poltekkes Kemenkes Yogyakarta, 2019.
[12] P. P. Novia Paulina, "Hubungan Panjang Badan Lahir dengan Kejadian Stunting pada Balita di Puskesmas Sentolo I Kulon Progo,” Poltekkes Kemenkes Yogyakarta, 2019.

[13] C. Ocvita Sari, "Hubungan Pola Asuh Ibu dengan Kejadian Stunting pada Balita Usia 25-59 Bulan di Wilayah Kerja Puskesmas Sentolo I Kabupaten Kulonprogo Yogyakarta Tahun 2018," Poltekkes Kemenkes Yogyakarta, 2019.

[14] Fitri AR; Lang CPZ; Framitasari D; Ratnasari F; Ringgo FMS; Hadiansyah H; Sumapraja K, "Hubungan Ukuran Lingkar Lengan Atas Ibu Hamil dengan Risiko Kejadian Persalinan Preterm di Puskesmas Kecamatan Kramat Jati Jakarta Timur The Correlation of Mid Upper Arm Circumference with A Risk of Preterm Labor in," eJournal Kedokt. Indones., vol. 2, no. 1, pp. 29-32, 2014

[15] O. Vitriani, P. Tegar Ardyta, and Hamidah, "Hubungan Lingkar Lengan Atas (Lila) Ibu Hamil Dengan Berat Badan Lahir Bayi Di Rumah Bersalin Cempedak Tahun 2013," Jurnal Ibu dan Anak, vol. 2, no. 1. pp. 1-6, 2018

[16] A. Ayunda, I. Firdawati, and W. D. Anjani, "Relationship Between Exclusive Breastfeeding With Stunting Events in Age 12-35 Months in Air Dingin Health Center Padang 2018," 1st Annu. Conf. Midwifery, vol. 1, pp. 301-308, 2020.

[17] S. Aisyatun, "Faktor yang Mempengaruhi Kejadian Stunting di Desa Dlemer Kecamatan Kwanyar Kabupaten Bangkalan,” Universitas Muhammadiyah Gresik, 2019.

[18] H. Swaminathan, A. Sharma, and N. G. Shah, "Does the relationship between income and child health differ across income groups? Evidence from India," Econ. Model., vol. 79, pp. 57-73, 2019.

[19] D. Vasundhara et al., "Maternal MUAC and fetal outcome in an Indian tertiary care hospital: A prospective observational study," Matern. Child Nutr., vol. 16, no. 2, pp. 1-8, 2020. 